\title{
Heparan Sulfate and Chondroitin Sulfate Glycosaminoglycans Are Targeted by Bleomycin in Cancer Cells
}

\author{
Xiulian Li ${ }^{a, b}$ Ying Lan ${ }^{a, b}$ Yanli He ${ }^{a, b}$ Yong Liua ${ }^{a, b}$ Heng Luo $0^{a, b}$ Haibo Yu \\ Ni Song ${ }^{a}$ Sumei Ren ${ }^{a}$ Tianwei Liub Cui Hao ${ }^{b}$ Yunliang Guo ${ }^{b}$ Lijuan Zhang \\ aSchool of Medicine and Pharmacy, Ocean University of China, Qingdao, China, 'bnstitute of \\ Cerebrovascular Diseases, Affiliated Hospital of Qingdao University, Qingdao, China, 'College of Animal \\ Science and Technology, Northwest A\&F University, Yangling, China
}

\section{Key Words}

Bleomycin $\bullet$ Heparan sulfate $\bullet$ Chondroitin sulfate $\cdot$ Glycosaminoglycan $•$ Cancer

\begin{abstract}
Background/Aims: Bleomycin is a clinically used anti-cancer drug that produces DNA breaks once inside of cells. However, bleomycin is a positively charged molecule and cannot get inside of cells by free diffusion. We previously reported that the cell surface negatively charged glycosaminoglycans (GAGs) may be involved in the cellular uptake of bleomycin. We also observed that a class of positively charged small molecules has Golgi localization once inside of the cells. We therefore hypothesized that bleomycin might perturb Golgi-operated GAG biosynthesis. Methods: We used stable isotope labeling coupled with LC/MS analysis of GAG disaccharides simultaneously from bleomycin-treated and non-treated cancer cells. To further understand the cytotoxicity of bleomycin and its relationship to GAGs, we used sodium chlorate to inhibit GAG sulfation and commercially available GAGs to compete for cell surface GAG/bleomycin interactions in seven cell lines including $\mathrm{CHO} 745$ defective in both heparan sulfate and chondroitin sulfate biosynthesis. Results: we discovered that heparan sulfate GAG was significantly undersulfated and the quantity and disaccharide compositions of GAGs were changed in bleomycin-treated cells in a concentration- and time-dependent manner. We revealed that bleomycin-induced cytotoxicity was directly related to cell surface GAGs. Conclusion: GAGs were targeted by bleomycin both at cell surface and at Golgi. Thus, GAGs might be the biological relevant molecules that might be related to the bleomycininduced fibrosis in certain cancer patients, a severe side effect with largely unknown molecular mechanism.
\end{abstract}




\section{Cellular Physiology Cell Physiol Biochem 2017;43:1220-1234

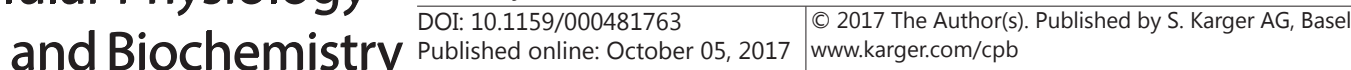 \\ Li et al.: Bleomycin Causes Undersulfation of Heparan Sulfate}

\section{Introduction}

Bleomycin - was discovered in 1962[1] and approved as an anticancer drug in Japan in 1969 and gained the US Food and Drug Administration (FDA) approval in 1973. Bleomycin is on the World Health Organization's List of Essential Medicines, the most important medications needed in a basic health system [2], due to its effective anticancer activities against testicular, cervical, ovarian, esophageal, head-neck, thyroid carcinomas and lymphomas $[3,4]$. Bleomycin's anticancer property relies on its ability to produce singleand double-stranded DNA breaks thus preventing DNA replications [5]. Unfortunately, Bleomycin also induces lung inflammation that lead to fibrosis and rapid death in certain cancer patients. The unexplainable side effect of bleomycin makes it an effective reagent in inducing lung fibrosis in a variety of animal models [6-8]. Up to date, it is still unknown the molecular targets of bleomycin that causes lung fibrosis. It is reasonable to assume that DNA might not be the only molecular target of bleomycin in animal cells.

Glycosaminoglycans (GAGs) are linear polysaccharides synthesized by all animal cells. Two major types of GAGs are heparan sulfate (HS) and chondroitin sulfate (CS) consisting of GlcN-GlcA/IdoA (glucuronic/Iduronic acid) and GalN-GlcA/IdoA as repeating disaccharide units, respectively. Because their repeating disaccharides can have diverse sulfation, GlcA or IdoA patterns due to differential expressions of GAG biosynthetic enzymes in different animal cells [9], the quantity and HS and CS compositions are varying not only from cell to cell but also from tissues to tissues [10]. GAGs interact with hundreds of proteins, including growth factors, cytokines, chemokines, proteases, protease inhibitors, coagulant and anticoagulant proteins, complement proteins, lipoproteins, and lipolytic enzymes [9, 11]. Rapid turnover [12] and structure diversity generated by both biosynthesis and post biosynthesis modification allow GAGs to regulate a myriad of signaling pathways $[13,14]$. Many proteoglycans and GAG modification enzymes, such as matrix metalloproteinase, heparanase, sulfatases, and hyaluronidases $[15,16]$, further expend the biological function of GAGs. Indeed, it has been well documented that GAGs play important roles in endocytosis, cell proliferation, apoptosis, differentiation, migration, collagen fiber formation, basement membrane regeneration, granulation tissue formation, inflammation, and other processes associated with cytotoxicity and fibrosis processes [17-21].

Properly sulfated GAGs are required for their biological activities. Reduced production of sulfated GAGs is associated with a form of severe malnutrition with high mortality characterized by edema and systemic abnormalities in children [22]. Undersulfated chondroitin sulfate is identified in neoplastic tissues [23]. Reduced sulfation in GAGs is reported in oncogene-activated [24], transformed [25] or viral infected cells [26]. However, small molecules that perturb GAG sulfation are limited to sodium chlorate, an inhibitor of the universal sulfate donor 3-phospho-adenyl-5- phosphosulfate (PAPS)[27] and D-xylosides, which act as artificial primers of GAG biosynthesis [28].Therefore, it is highly important to know if other chemical reagents or drugs that also inhibit GAG sulfation.

Even though bleomycin interrupts DNA replications once inside of cells $[3,29]$, the $\mathrm{IC}_{50}$ of bleomycin varies greatly in different cancer cell lines [30]. It turns out that bleomycin does not diffuse through the plasma membrane but gets inside cells through receptor-mediated endocytosis. However, the molecular nature of the receptor is still unclear. In contrast, proteoglycans are well established cell-surface endocytosis receptors [31, 32]. A unique Chinese hamster ovary cell mutant defective in cell surface GAG biosynthesis (CHO745) [33] is a commonly used cell line to study the role of GAGs and proteoglycans played in endocytosis $[32,34]$. Based on these facts, we assumed that the positively charged groups in bleomycin may interact with negatively charged GAGs on proteoglycans for its cellular uptake. Indeed, by treating seven different cell lines with bleomycin, including the CHO745, the cytotoxicity data suggested that GAGs might be involved in the cellular uptake of bleomycins [35]. Since bleomycin has no optical properties, we have synthesized a series of small molecules with intrinsic fluorescence with or without positive charge, i.e. isothiouronium- or bromomodified curcumin-pyrimidine analogs. We found that only the positively charged molecules 


\section{Cellular Physiology Cell Physiol Biochem 2017;43:1220-1234

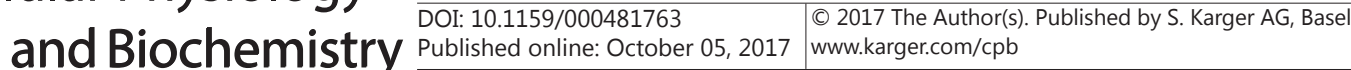

Li et al.: Bleomycin Causes Undersulfation of Heparan Sulfate

have a Golgi localization once inside of the cells [36]. Based on the facts, we hypothesized that bleomycin might perturb Golgi-operated GAG biosynthesis.

Bleomycin-induced changes in proteoglycans have been reported [37, 38]. However, direct effects of bleomycin on GAG structures and GAG-related signaling complex formation, and alterations in disaccharide composition and sulfation in GAGs have not been well documented due to technical difficulties in GAG structural analysis. Only the changes of disaccharide compositions of CS and dermatan sulfate (DS or CS-B) have been evaluated by fluorophore-assisted carbohydrate electrophoresis (FACE) in a bleomycin-treated rat model [39]. In current study, by using a novel stable isotope-labeling strategy, we showed that bleomycin reduced HS sulfation and altered CS quantity and disaccharide compositions in a concentration- and time-dependent manner based on LC-MS analysis. Therefore, bleomycin reduced HS sulfation in cancer cells with a molecular mechanism different from that of sodium chlorate and $\beta$-xylosides. Moreover, the novel GAG structural analysis methods and the GAG data provided in current study should be valuable in understanding the roles of GAGs played in bleomycin's cytotoxicity and bleomycin-induced lung fibrosis in future.

\section{Materials and Methods}

\section{Cell culture and growth inhibition assay}

HCT116 and HT29 cells (Type culture collection of the Chinese Academy of Sciences, China) were maintained in McCoy's 5A media (Gibco, USA). H1299 and A549 cells (Type culture collection of the Chinese academy of sciences, China) were maintained in RPMI-1640 media (Hyclone, USA) as described previously [40]. Chinese hamster ovary (CHOK1, CHO 745, CHO 3.1) cells (gifts from Dr. Jeffrey D. Esko, University of California San Diego) were maintained in DMEM/F12 media (Hyclone, USA) supplemented with 5\% heatinactivated FBS (Gibco, USA), $100 \mathrm{U} / \mathrm{mL}$ of penicillin, and $0.1 \mathrm{mg} / \mathrm{mL}$ of streptomycin (Gibco, USA) at $37^{\circ} \mathrm{C}$ with $5 \% \mathrm{CO}_{2}$ and $95 \%$ air in the incubator. All cells used were between 3 and 30 passages. DMSO (Solarbio, China) was used to dissolve bleomycin (Nippon Kayaku Co., Ltd., Japan) and the final concentration of DMSO in all cell-related experiments was 0.1\%. For cell growth inhibition assay, HCT116, HT29, A549, H1299, CHO K1, CHO 745, CHO 3.1 cells were seeded in 96-well plates with 2000 cells in each well. After 24 h, cells were treated with serial concentrations of the bleomycin $(10,20,40,80$, and $160 \mu \mathrm{M})$ in $200 \mu \mathrm{L}$ of complete media. After $48 \mathrm{~h}$, each well was added $20 \mu \mathrm{L}$ of $2 \mathrm{mg} / \mathrm{mL}$ resazurin (Sigma, USA) solution. After $16 \mathrm{~h}$ of incubation at $37^{\circ} \mathrm{C}$, the fluorescent signal was monitored by using Spectramax M5 plate reader (Molecular Devices, USA) at $544 \mathrm{~nm}$ excitation wavelength and $595 \mathrm{~nm}$ emission wavelength. The relative fluorescence unit (RFU) generated from the assay was proportional to the number of living cells in each well.

The effects of sodium chlorate in cell culture media on the cytotoxicity induced by bleomycin

Sulfation reactions can be inhibited when animal cells are treated with sodium chlorate [27]. In our experiment, HCT116, A549, and CHO 745 cells were seeded in 96-well plates with 2000 cells in each well. After $12 \mathrm{~h}$, cells were incubated with different concentrations (0.016-10 mM) of sodium chlorate for 12 $\mathrm{h}$ in $150 \mu \mathrm{L}$ of complete media. After $12 \mathrm{~h}$, each well was added $50 \mu \mathrm{L}$ of complete media with or without bleomycin $(15 \mu \mathrm{M})$ for $48 \mathrm{~h}$. After $48 \mathrm{~h}$, each well was added $20 \mu \mathrm{L}$ of resazurin $(2 \mathrm{mg} / \mathrm{mL}$ dissolved in water, filtrate with $0.22 \mu \mathrm{m}$ filter membrane). After $16 \mathrm{~h}$ of incubation at $37^{\circ} \mathrm{C}$, the fluorescent signal was monitored by using Spectramax M5 plate reader at $544 \mathrm{~nm}$ excitation wavelength and $595 \mathrm{~nm}$ emission wave lengths.

Adding GAGs to cell cultural media to compete cell surface GAG and bleomycin binding to inhibit endocytosis thus cytotoxicity

HCT116, A549, and CHO 745 cells were seeded in 96-well plates with 2000 cells in each well. After $24 \mathrm{~h}$, cells were incubated with bleomycin $(15 \mu \mathrm{M})$ in the presence or absence of varying concentrations of soluble GAG $(0.15 \mu \mathrm{M}, 1.5 \mu \mathrm{M}, 15 \mu \mathrm{M})$ for $48 \mathrm{~h}$ in $200 \mu \mathrm{L}$ of complete media. After $48 \mathrm{~h}$, each well was added $20 \mu \mathrm{L}$ of resazurin $(2 \mathrm{mg} / \mathrm{mL}$ dissolved in water, filtrate with $0.22 \mu \mathrm{m}$ filter membrane $)$. After $16 \mathrm{~h}$ of incubation at $37^{\circ} \mathrm{C}$, the fluorescent signal was monitored by using Spectramax M5 plate reader at $544 \mathrm{~nm}$ excitation wavelength and $595 \mathrm{~nm}$ emission wave lengths. 


\section{Cellular Physiology Cell Physiol Biochem 2017;43:1220-1234



Li et al.: Bleomycin Causes Undersulfation of Heparan Sulfate

\section{Purification of GAGs from control and bleomycin-treated cells}

The method is a modified version of the previously published one [41]. Cells $\left(2.2 \times 10^{6}\right)$ were seeded in each $15 \mathrm{~cm}$ diameter cell culture dish. Five dishes of control cells (0.1\% DMSO treated) and 8 dishes of Bleomycin treated cells with a final DMSO concentration of $0.1 \%$ were used for GAG preparations. The cells in each dish were incubated in $5 \mu \mathrm{M}$ of bleomycin for $48 \mathrm{~h}, 80 \mu \mathrm{M}$ of bleomycin for $4 \mathrm{~h}$, or $0.1 \%$ DMSO for $48 \mathrm{~h}$ or $4 \mathrm{~h}$, respectively, in McCoy's $5 \mathrm{~A}$ media in a final volume of $20 \mathrm{~mL}$ at $37^{\circ} \mathrm{C}$ with $5 \% \mathrm{CO}_{2}$ and $95 \%$ air in the incubator.

GAGs were then extracted from the control and bleomycin treated cells by a previously published procedure [42] with minor modifications. The cells in each dish were first hydrolyzed by using $10 \mathrm{~mL}$ $100 \mathrm{mM} \mathrm{NaOH}$. The cell lysates were collected in a $50 \mathrm{~mL}$ tube and incubated at $4^{\circ} \mathrm{C}$ overnight to release the GAG chains from core proteins by $\beta$-elimination reaction followed by adjusting the $\mathrm{pH}$ to 6.0 using 6 $\mathrm{M} \mathrm{HCl}$. Cell lysate $(100 \mu \mathrm{L})$ from each group was collected and stored at $-40^{\circ} \mathrm{C}$. They were later used for protein quantification to calculate the GAG/protein ratio by using the BCA protein assay kit (Beyotime Biotechnology Co. Ltd., China). Protease ( $0.1 \mathrm{~g} /$ sample) (Tianshi corporation, China) was added to each 50 $\mathrm{mL}$ tube to digest GAG binding proteins by incubating at $37^{\circ} \mathrm{C}$ overnight. The protease was then inactivated by heating the tube in a $100^{\circ} \mathrm{C}$ water bath for $15 \mathrm{~min}$. The supernatant was collected by centrifuging at room temperature at $4500 \mathrm{r} / \mathrm{min}$ for $15 \mathrm{~min}$ and the $\mathrm{pH}$ was adjusted to 6.0 by using $1 \mathrm{M} \mathrm{HCl}$. Anion exchange resin $(0.5 \mathrm{~mL})$ was added into each tube and shook for $3 \mathrm{~h}$. The supernatant was aspirated and the beads were washed three times with $3 \mathrm{~mL} 0.25 \mathrm{M} \mathrm{NaCl}, 0.01 \%$ Triton X-100, $20 \mathrm{mM} \mathrm{NaAc} \mathrm{pH} 6.0$ by re-suspension and centrifugation ( $5 \mathrm{~min}$ ). The GAGs were pooled from the supernatants by three successive $500 \mu \mathrm{L} 1.0 \mathrm{M} \mathrm{NaCl}$, $0.01 \%$ Triton X-100, $20 \mathrm{mM} \mathrm{NaAc} \mathrm{pH} 6.0$ elution steps. The GAGs were precipitated by adding $100 \%$ ethanol to the supernatant with the final ethanol concentration of $80 \%$ for at least $2 \mathrm{~h}$ at $4^{\circ} \mathrm{C}$. The precipitated GAGs were collected by centrifugation for $15 \mathrm{~min}$ at $4500 \mathrm{r} / \mathrm{min}$ and the supernatant was aspirated. The GAG pellet was washed with $0.5 \mathrm{~mL}$ of $75 \%$ ethanol. The GAGs in the dried pellet were dissolved in water in a siliconized tube and stored at $4{ }^{\circ} \mathrm{C}$ for further analysis.

\section{Generating HS and CS disaccharide by enzymatic digestion}

GAGs were divided into two parts, one for HS disaccharide analysis and the other for CS disaccharide analysis. For HS digestions, GAGs were incubated with $0.33 \mathrm{mU}$ each of heparin lyase I, II, III (Biokangtai Pharmaceuticals, Inc., China) in a final volume of $50 \mu \mathrm{L} 5 \mathrm{mM} \mathrm{NH}_{4} \mathrm{Ac} \mathrm{pH} 7.0$ in the presence of $0.125 \mathrm{mM}$ $\mathrm{CaCl}_{2}$. To ensure the completion of the digestion, the digests were incubated at $37^{\circ} \mathrm{C}$ overnight after adding another round of the enzymes. For CS digestions, GAGs were incubated in $50 \mu \mathrm{L}$ of digestion solution containing $5 \mathrm{mM}$ ammonium acetate $\mathrm{pH} 7.0$ and $1 \mathrm{mU}$ chondroitinase ABC (Biokangtai Pharmaceuticals, Inc., China). Digestion was monitored by increased absorbance at $232 \mathrm{~nm}$ by using a Spectra MAX M2 platereading spectrophotometer with the temperature of the plate chamber set at $37^{\circ} \mathrm{C}[42]$.

\section{PMP labeling}

Five $\mu \mathrm{L}$ of $\mathrm{NH}_{3} \cdot \mathrm{H}_{2} \mathrm{O}$ and $50 \mu \mathrm{L}$ labeling reagents (either $0.5 \mathrm{M} \mathrm{PMP}$ or $0.5 \mathrm{M} \mathrm{2,3,4,5,6-deuterated} \mathrm{PMP}$ (D5PMP) dissolved in methanol) were added into the enzyme-digested samples and 0.5 M PMP (Sigma, USA) were added into the unsaturated HS and CS disaccharide standards (Sigma, USA). The labeling reaction was conducted for $1 \mathrm{~h}$ at $70^{\circ} \mathrm{C}$. The $\mathrm{NH}_{3} \cdot \mathrm{H}_{2} \mathrm{O}$ was removed in a speed-vac. The extra PMP or D5PMP (synthesized by our laboratory) in the labeling reaction was extracted by using 1:2.5 volumes of chloroform three times. The PMP- and D5PMP- labeled products from the same amount of cellular proteins were mixed and ready for Liquid chromatography coupled mass spectrometry (LC/MS) analysis.

\section{LC/MS analysis}

The PMP-labeled commercial HS or CS disaccharide standards or the mixture of PMP- and D5PMPlabeled products were separated by using Agilent 1200 infinity capillary liquid chromatography system with a ZORBAX Stable Bond chromatogram column $(5 \mu \mathrm{m}, 0.5 \times 250 \mathrm{~mm}$ ). Solvent A was $10 \mathrm{mM}$ ammonium acetate (pH 5.0); Solvent B was 100\% acetonitrile. For HS analysis, the gradient used was $17-22 \%$ B in 60 $\mathrm{min}$ and $23 \% \mathrm{~B}$ for another $15 \mathrm{~min}$ and equilibrated with $17 \%$ B. For CS analysis, the gradient used was $13 \%$ B in $30 \mathrm{~min}, 20 \%$ B for $10 \mathrm{~min}$ and equilibrated with $13 \%$ B. The flow rate was $10 \mu \mathrm{L} / \mathrm{min}$. The UV absorbance of PMP labeled products was monitored at $245 \mathrm{~nm}$ by using an online UV detector and the total 


\section{Cellular Physiology Cell Physiol Biochem 2017;43:1220-1234

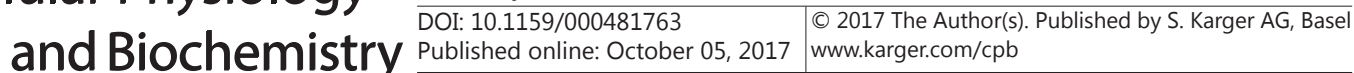 \\ Li et al.: Bleomycin Causes Undersulfation of Heparan Sulfate}

ion current (TIC) was collected using a Thermo LTQ-XL mass spectrometer operating in negative ion mode by scanning the $\mathrm{m} / \mathrm{z}$ ranged from 300-2000. The mass chromatograms were processed by using Thermo Xcalibur software.

\section{Statistical analysis}

All statistical calculations were done using IBM SPSS Statistics 21. All data are represented as the mean \pm S.D. Comparison between groups was made by Student's t-test to analyze the difference. $\mathrm{P}<0.05$ was considered to have statistical significance.

\section{Results}

Pair-wised comparison of the quantitative changes in each CS and HS disaccharide in bleomycin-treated vs. non-treated A549 and HCT116 cells

We hypothesized that bleomycin might perturb Golgi-operated GAG biosynthesis. To test, detailed GAG structural characterization from bleomycin-treated cell culture is required. We previously reported that $\mathrm{IC}_{50}$ values for bleomycinin lung cancer A549 and colon cancer HCT116 cells are 17.5 \pm 2.4 and $13.4 \pm 1.7 \mu \mathrm{M}$, respectively [35]. Based on the published cytotoxicity study, a large proportion of cells will die after treating the cells with high concentration of bleomycin for an extended period of time [35]. To evaluate how bleomycin affected GAG biosynthesis and metabolism, we treated A549 and HCT116 cells with bleomycin either at high concentration for a short period of time (HCST: $80 \mu \mathrm{M} 4 \mathrm{~h}$ ) or low concentration for a long period of time (LCLT: $5 \mu \mathrm{M} 48 \mathrm{~h}$ ). Non-bleomycin treated cells were cultured at same time to serve as control. The final DMSO concentrations in all cell cultures were $0.1 \%$. We then isolated GAGs from these cell cultures, respectively (See details in Materials and methods).

In GAG research field, disaccharide compositional analysis is used for GAG structural characterization. Of the different technologies available, LC/MS is the most robust method because of its higher sensitivity and accuracy. To facilitate quantitative comparison of GAG disaccharide compositions from different cell types, we have previously tagged the reducing end of enzyme-digested disaccharides with aniline-containing normal and stable isotopes [41]. Because different isotope tags have no effect on LC retention times but are discriminated by MS analysis, differentially isotope-tagged disaccharides can be compared simultaneously

Table 1. Molecular masses for PMP- or D5PMP-labeled HS and CS disaccharides detected in bleomycintreated or control A549 and HCT116 cells. The disaccharide structure code (DSC)[59], the abbreviated chemical structure $(\Delta U=4,5$-unsaturated uronic acid), and the observed $\mathrm{m} / \mathrm{z}$ values in negative ion mode for each enzymatically derived disaccharide are listed

\begin{tabular}{lccc}
\hline Disaccharide Code & Structures & Observed m/z (z=1) & \\
& & PMP-labeled & D5PMP-labeled \\
\hline CS disaccharides & & 708 & 718 \\
D0a0 & UUA-GalNAc & 788 & 798 \\
D0a6 & $\Delta$ UA-GalNAc6S & 788 & 798 \\
D0a4 & $\Delta$ UA-GalNAc4S & & \\
HS disaccharides & & 708 & 718 \\
D0A0 & $\Delta$ UA-GlcNAc & 788 & 798 \\
D2A0 & $\Delta$ UA2S-GlcNAc & 788 & 798 \\
D0A6 & $\Delta$ UA-GlcNAc6S & 746 & 756 \\
D0H6 & $\Delta$ UA-GlcN6S & 746 & 756 \\
D0S0 & $\Delta$ UAA-GlcNS & 746 & 756 \\
D2H0 & $\Delta$ UA2S-GlcN & 826 & 836 \\
D2S0 & $\Delta$ UA2S-GlcNS & & \\
\hline
\end{tabular}




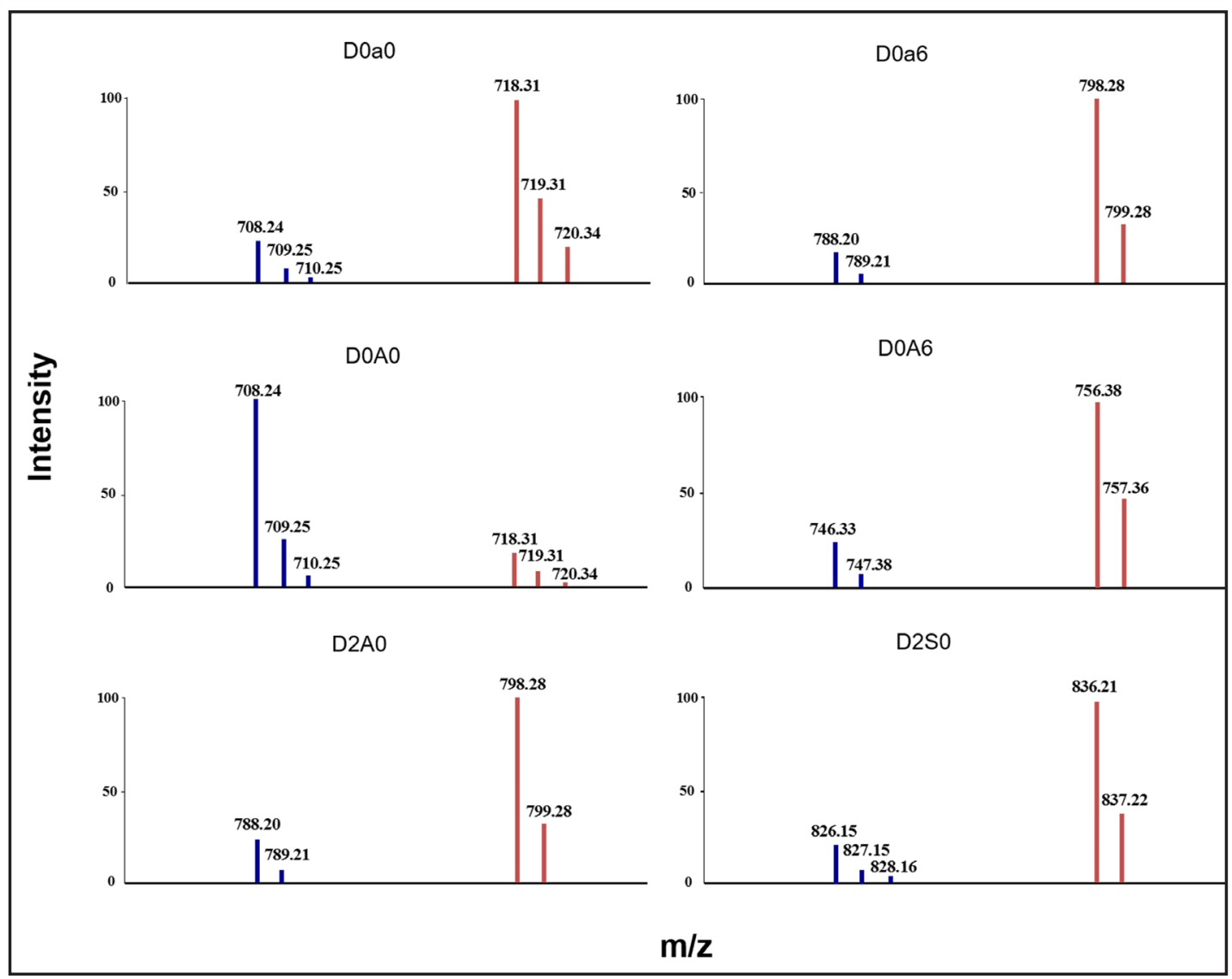

Fig. 1. MS data of six representative CS and HS disaccharides from the PMP labeled (blue, bleomycintreated, $5 \mu \mathrm{M} 48 \mathrm{~h}$ ) and D5PMP-labeled (red, the control, $0 \mu \mathrm{M} 48 \mathrm{~h}$ ) sample from A549 cells. HS and CS disaccharides from enzymatically digested GAGs isolated from bleomycin-treated or control A549 cells were tagged with PMP or D5PMP, respectively. The two independently labeled samples were proportionally admixed to ensure that each sample was from the same amount of cell-proteins. The co-injected mixture was then subjected to LC/MS analysis. Since each disaccharide can be tagged with two molecules of PMP or D5PMP, each co-eluted pair of PMP- and D5PMP-labeled disaccharide should have 10 mass unit difference in theory, which was exactly observed in the MS data shown above. All disaccharides were further identified by directly comparing both LC elution positions and $\mathrm{m} / \mathrm{z}$ data with that of PMP-labeled, commercially available disaccharide standards (See details in Materials and methods).

by LC/MS [41]. In current study, we firstly digested the purified GAGs into disaccharides enzymatically and then compared CS and HS disaccharide compositions generated from bleomycin-treated (PMP labeling) and control (D5PMP labeling) A549 and HCT116 GAG samples by LC-MS analysis quantitatively (See details in Materials and methods).

The molecular masses over charge (m/z) for all PMP- or D5PMP-labeled HS and CS disaccharides observed in bleomycin-treated or control A549 and HCT116 cells detected by MS were summarized in Table 1 . Since every disaccharide is tagged with two molecules of PMP or D5PMP[43], there were 10 atomic mass unit differences between the same disaccharide labeled with PMP and D5PMP constantly.

The representing extracted ion current of six pairs of CS and HS disaccharides from HCST bleomycin-treated (PMP-labeled, blue) and control (D5PMP-labled, red) A549 cells were shown in Fig. 1. The ion current intensities of CS disaccharides ( $\triangle$ UA-GalNAc/D0a0) and $\triangle \mathrm{UA}$-GalNAc6S/D0a6) were lower in the bleomycin-treated vs. control based on the same protein loading. In contrast, the non-sulfated HS disaccharide ( $\triangle \mathrm{UA}-\mathrm{GlcNAc} / \mathrm{D} 0 \mathrm{~A} 0$ ) was increased in the bleomycin-treated sample whereas the monosulfated ( $\triangle \mathrm{UA2S}$-GlcNAc/ 
D2A0, $\triangle$ UA-GlcNAc6S/D0A6) and di-sulfated HS disaccharides ( $\triangle$ UA2S-GlcNS/D2S0) were deceased in the bleomycin-treated sample significantly, indicating bleomycin reduced the sulfation of both mono- and di-sulfated disaccharide in HS.

The CS and HS disaccharide compositions of bleomycin-treated or control A549 and HCT116 cells

Since we used a solvent gradient to separate each disaccharide by LC (See details in Materials and methods), the ion current intensity of the PMP- or D5PMP-labeled disaccharides increased with increased acetonitrile concentrations during the LC/MS analysis. Thus we used commercially available disaccharides to obtain the response factor for each disaccharide based on the method used in our previous publication [42]. The CS and HS disaccharide compositions were then calculated based on MS data and summarized in Table 2.

First of all, CS and HS disaccharide compositions in A549 and HCT116 cells were different (Table 2). Secondly, the percentage of non-sulfated HS disaccharide (D0A0) was greatly increased and all sulfated HS disaccharides were deceased in all bleomycin-treated GAG cells compared to the controls. In contrast, BLEOMYCIN treatment did not change the CS disaccharide compositions as drastically as that of HS (Table 2). Thirdly, CS and HS compositions at two different bleomycin treatment conditions were different from each other (Table 2). Interestingly, HS disaccharide D0A6 was present in LCLT culture of both bleomycin and control A549 cells but was undetectable in HCST culture of both bleomycin and control A549 cells (Table 2). In contrast, D0A6 was present in HCST culture of both bleomycin and control HCT116 cells but was undetectable in LCLT culture of both bleomycin and control HCT116 cells (Table 2).

\section{Bleomycin-induced changes in CS and HS disaccharides of A549 and HCT116 cells}

The bleomycin-induced \% changes in each HS or CS disaccharide compared to control in all samples were calculated (Table 3) and plotted in Fig. 2, based on the disaccharide

Table 2. Disaccharide compositions of HS and CS from bleomycin-treated and untreated A549 and HCT116 cells (Percentage of each disaccharide in total disaccharides). Disaccharides from enzymatically digested HS and CS isolated from bleomycin-treated and untreated A549 and HCT116 cells were tagged with PMP or D5PMP, respectively. The 8 sets of PMP- or D5PMP-labeled samples were proportionally admixed to ensure equal cell-protein loading into 4 samples: A549 (LCLT: bleomycin + Control); A549 (HCST: bleomycin + Control); HCT116 (LCLT: bleomycin + Control); HCT116 (HCST: bleomycin + Control) before LC/MS analysis. The disaccharide compositions were calculated based on the MS signal intensity. Data are expressed as percentage of total disaccharide (mean +/- S.D., $\mathrm{n}=3$ ); bleomycin treatment conditions: LCLT (5 $\mu \mathrm{M} 48 \mathrm{~h}$ ) and HCST $(80 \mu \mathrm{M} 4 \mathrm{~h}) ; \mathrm{ND}$, not detected; ${ }^{*} \mathrm{P}<0.05$ vs control

\begin{tabular}{|c|c|c|c|c|c|c|c|c|}
\hline \multicolumn{5}{|c|}{ A549 } & \multicolumn{4}{|c|}{ HCT116 } \\
\hline & LCLT & LCLT & HCST & HCST & LCLT & \multirow{2}{*}{ LCLT Control } & HCST & \multirow{2}{*}{ HCST Control } \\
\hline & BLM & Control & BLM & Control & BLM & & BLM & \\
\hline \multicolumn{9}{|c|}{ CS disaccharides } \\
\hline DOaO & $24.9 \pm 2.2$ & $30.0 \pm 4.0$ & $31.9 \pm 1.1 *$ & $36.2 \pm 0.8$ & $28.0 \pm 3.0^{*}$ & $19.0 \pm 1.0$ & $22.7 \pm 1.3^{*}$ & $30.6 \pm 2.6$ \\
\hline D0a6 & $16.0 \pm 3.0 *$ & $32.7 \pm 2.7$ & $23.8 \pm 3.8^{*}$ & $33.9 \pm 2.1$ & $34.8 \pm 1.2^{*}$ & $38.7 \pm 1.3$ & $41.5 \pm 3.5^{*}$ & $32.6 \pm 2.4$ \\
\hline D0a4 & $59.1 \pm 2.9^{*}$ & $37.3 \pm 5.7$ & $44.3 \pm 4.3^{*}$ & $29.9 \pm 2.1$ & $37.2 \pm 2.2$ & $42.3 \pm 3.7$ & $35.8 \pm 2.2$ & $36.8 \pm 0.8$ \\
\hline \multicolumn{9}{|c|}{ HS disaccharides } \\
\hline DOAO & $91.2 \pm 2.9 *$ & $25.4 \pm 4.9$ & $83.0 \pm 7.0$ & $69.9 \pm 5.1$ & $92.5 \pm 7.5^{*}$ & $31.2 \pm 5.2$ & $88.8 \pm 4.2^{*}$ & $37.9 \pm 5.1$ \\
\hline D2A0 & $1.8 \pm 0.6^{*}$ & $14.0 \pm 2.3$ & ND & $4.9 \pm 1.0$ & $3.6 \pm 0.9 *$ & $14.1 \pm 2.3$ & ND & $11.2 \pm 1.8$ \\
\hline D0A6 & $1.0 \pm 0.4^{*}$ & $12.9 \pm 3.5$ & ND & ND & ND & ND & $2.6 \pm 0.6^{*}$ & $8.6 \pm 1.3$ \\
\hline DOH6 & $2.1 \pm 0.3^{*}$ & $14.4 \pm 2.3$ & $5.0 \pm 1.3^{*}$ & $7.6 \pm 0.4$ & $1.8 \pm 0.3^{*}$ & $15.1 \pm 3.8$ & $3.7 \pm 1.1^{*}$ & $10.9 \pm 2.9$ \\
\hline Doso & $1.6 \pm 0.5^{*}$ & $13.0 \pm 1.9$ & $2.3 \pm 1.2^{*}$ & $6.7 \pm 1.5$ & $1.3 \pm 0.3^{*}$ & $13.8 \pm 2.9$ & $1.7 \pm 1.1^{*}$ & $9.2 \pm 3.1$ \\
\hline D2HO & $0.9 \pm 0.5^{*}$ & $11.5 \pm 3.3$ & $6.7 \pm 1.5$ & $5.3 \pm 1.2$ & ND & $12.9 \pm 4.3$ & $1.6 \pm 1.1^{*}$ & $11.1 \pm 5.2$ \\
\hline D2So & $1.3 \pm 0.7^{*}$ & $8.8 \pm 1.5$ & $3.0 \pm 1.5$ & $5.5 \pm 1.5$ & $0.9 \pm 0.4^{*}$ & $13.0 \pm 5.3$ & $1.6 \pm 0.6^{*}$ & $11.1 \pm 5.7$ \\
\hline
\end{tabular}




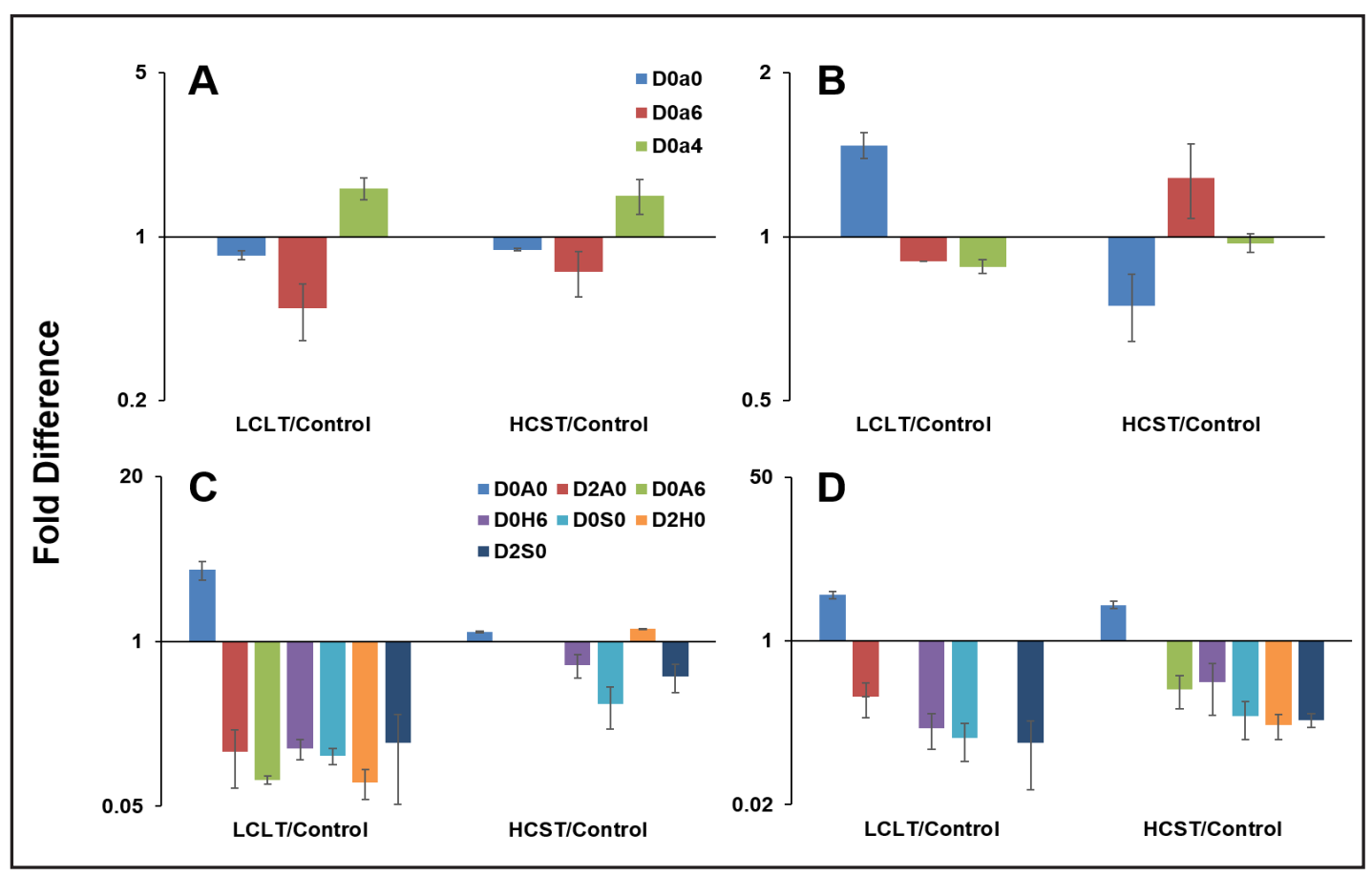

Fig. 2. Bleomycin-induced changes in CS and HS disaccharides. The fold quantity differences in CS and HS disaccharides between bleomycin-treated and control cells were derived by calculating the ratio of each coeluted pair of disaccharide, i.e. the PMP-labeled disaccharide\% from bleomycin treated cells was divided by the D5PMP-labeled disaccharide\% from the control cells as shown in Table 2. Data are expressed as mean +/- S.D. from three independent measurements. A: CS disaccharides from A549 cells (LCLT or HCST); B: CS disaccharides from HCT116 cells (LCLT or HCST). C: HS disaccharides from A549 cells (LCLT or HCST); D: HS disaccharides from HCT116 cells (LCLT or HCST). bleomycin treatment conditions: LCLT (5 $\mu$ M $48 \mathrm{~h})$ and HCST $(80 \mu \mathrm{M} 4 \mathrm{~h})$.

composition data shown in Table 2. The results indicated that bleomycin treatment reduced the amount of all three CS disaccharides and all the sulfated HS disaccharides differentially. Most strikingly, the amount of non-sulfated HS disaccharide ( $\triangle \mathrm{UA}-\mathrm{GlcNAc}$ / D0A0) was increased 2 to 3 fold in the bleomycin-treated A549 and HCT116 cells regardless the bleomycin concentration and treatment time used for cell culture. Furthermore, all sulfated HS disaccharides were decreased in the bleomycin-treated A549 and HCT116 cells significantly.

\section{Bleomycin had GAG-dependent cytotoxicity}

Previous studies showed that the plasma membrane acts as barrier to limit the entry of the positively charged bleomycin into cells $[44,45]$. This is supported by the observation that electroporation can increase the level of bleomycin into mammalian cells thereby enhancing the genotoxicity of the drug $[29,46,47]$. In the following experiment, the cytotoxic effect of bleomycin on HCT116 was directly compared with that of human lung cancer cells A549 and H1299, human colon cancer cell HT29, and three Chinese hamster ovary (CHO) cell lines, CHO K1, CHO 745, and CHO 3.1 cells, where CHO 745 is cell surface GAG-deficient cell line, CHO K1 is the wild-type control, CHO 3.1 is a HS 3-osulfotransferase-1 over-expressing cell line. The $\mathrm{IC}_{50}$ values bleomycin in the 7 cell lines were shown in Table 4. Among the four cancer cell lines tested, HCT116 was most sensitive to bleomycin-induced cytotoxicity. In three $\mathrm{CHO}$ cell lines, bleomycin was more toxic to $\mathrm{CHO} \mathrm{K} 1$ and CHO3.1 cells than that of $\mathrm{CHO}$ 745 , which suggested that lacking cell surface GAGs in CHO 745 made it less susceptible to bleomycin's cytotoxicity, indicating GAGs might be involved in endocytosis of bleomycin.

\section{KARGER}




\section{Cellular Physiology Cell Physiol Biochem 2017;43:1220-1234 and Biochemistry DOI: 10.1159/000481763 $20 \begin{aligned} & \text { O } 2017 \text { The Author(s). Published by S. Karger AG, Basel } \\ & \text { www.karger.com/cpb }\end{aligned}$

Table 3. Bleomycin-induced changes of specific HS and CS disaccharides in A549 and HCT116 cells compared to control. "个" indicates the disaccharide was increased vs. that of control; " $\downarrow$ " indicates the disaccharide was decreased vs. that of control; ND, not detected. Bleomycin treatment conditions: LCLT ( $5 \mu \mathrm{M} 48 \mathrm{~h})$ and $\operatorname{HCST}(80 \mu \mathrm{M} 4 \mathrm{~h})$

\begin{tabular}{lcccc}
\hline & & A549 & & HCT116 \\
\hline CS disaccharides & LCLT & HCST & LCLT & HCST \\
D0a0 & $\downarrow$ & & & \\
D0a6 & $\downarrow$ & $\downarrow$ & $\downarrow$ & $\downarrow$ \\
D0a4 & $\downarrow$ & $\downarrow$ & $\downarrow$ & $\uparrow$ \\
HS disaccharides & $\uparrow$ & $\uparrow$ & $\downarrow$ \\
D0A0 & $\uparrow$ & $\uparrow$ & $\uparrow$ & \\
D2A0 & $\downarrow$ & ND & $\downarrow$ & ND \\
D0A6 & $\downarrow$ & ND & ND & $\downarrow$ \\
D0H6 & $\downarrow$ & $\downarrow$ & $\downarrow$ & $\downarrow$ \\
D0S0 & $\downarrow$ & $\downarrow$ & $\downarrow$ & $\downarrow$ \\
D2H0 & $\downarrow$ & $\uparrow$ & ND & $\downarrow$ \\
D2S0 & $\downarrow$ & $\downarrow$ & $\downarrow$ & $\downarrow$ \\
\hline
\end{tabular}

Table 4. $\mathrm{IC}_{50}(\mu \mathrm{M})$ values of bleomycin in different cell lines

\begin{tabular}{lccccccc}
\hline Cell Lines & HCT116 & HT29 & A549 & H1299 & CHO 745 & CHO K1 & CHO 3.1 \\
\hline IC50 of BLM & $13.4 \pm 1.7$ & $71.2 \pm 0.2$ & $17.5 \pm 2.4$ & $233.4 \pm 5.2$ & $>500$ & $446.6 \pm 3.4$ & $129.3 \pm 6.1$ \\
\hline
\end{tabular}

To clarify if GAG sulfation was required for the endocytosis-led cytotoxicity of bleomycin, we treated HCT116, A549, and CHO 745 cells with the reversible sulfation inhibitor, sodium chlorate [48] (Fig. 3). When concentrations were varied from 0.016 to $10 \mathrm{mM}$, sodium chlorate did not alter cell viability as shown in Fig. 3. However, the cytotoxicity of bleomycin to A549 and HCT116 cells was significantly reduced by the addition of sodium chlorate (from 0.016 to $10 \mathrm{mM}$ ). In contrast, at comparable concentrations, the cytotoxicity of bleomycin to CHO 745 cells was significantly increased. Thus, sulfation was partially helped cellular uptake of bleomycin for both A549 and HCT116 cells whereas chlorate treatment had opposite effects on the GAG-deficient CHO 745 cells in the presence of bleomycin. Therefore, proper sulfated cell surface GAGs might be responsible for the uptake of bleomycin in A549 and HCT116 cells.

For an additional confirmation, we performed competitive binding assays by adding soluble GAGs, including CS-A, CS-B, CS-C, CS-D, CS-E, HS, and heparin to cell culture media to inhibit cell surface GAG/bleomycin binding. We used low, meddle, and high concentrations for each GAG with bleomycin or bleomycin alone for the inhibition experiment. Among the GAGs used, CS-A consists of mainly GlcA-GalNAc4S repeating disaccharides, CS-B contains both IdoA-GalNAc4S and GlcA-GalNAc4S as dominant repeating disaccharides, and CS-C consists of mainly GlcA-GalNAc6S repeating disaccharides. CS-D and CS-E are enriched in disulfated disaccharides, GlcA2S-GalNAc6S and GlcA-GalNAc4S6S, respectively. Heparan sulfate is from bovine kidney and heparin is from porcine mucosa. The data in Fig. 4 showed that high concentration of CS-A, CS-B, CS-C and Heparan almost reversed the cytotoxicity of bleomycin in HCT116 cells. Strikingly, all the GAGs at low, medium, and high concentrations reduced cytotoxicity of bleomycin in both HCT116 and A549 cells, especially A549 cells. In contrast, low, middle and high concentration of CS-A significantly increased cytotoxicity of bleomycin in GAG-deficient CHO 745 cells (Fig. 4).

\section{Discussion}

The data in Fig. 2, Tables 2 \& 3 showed that HS was significantly undersulfated in both bleomycin-treated HCT116 and A549 cells and the HS and CS disaccharide compositions were very different in the bleomycin-treated and untreated HCT116 and A549 cells. Moreover, the 


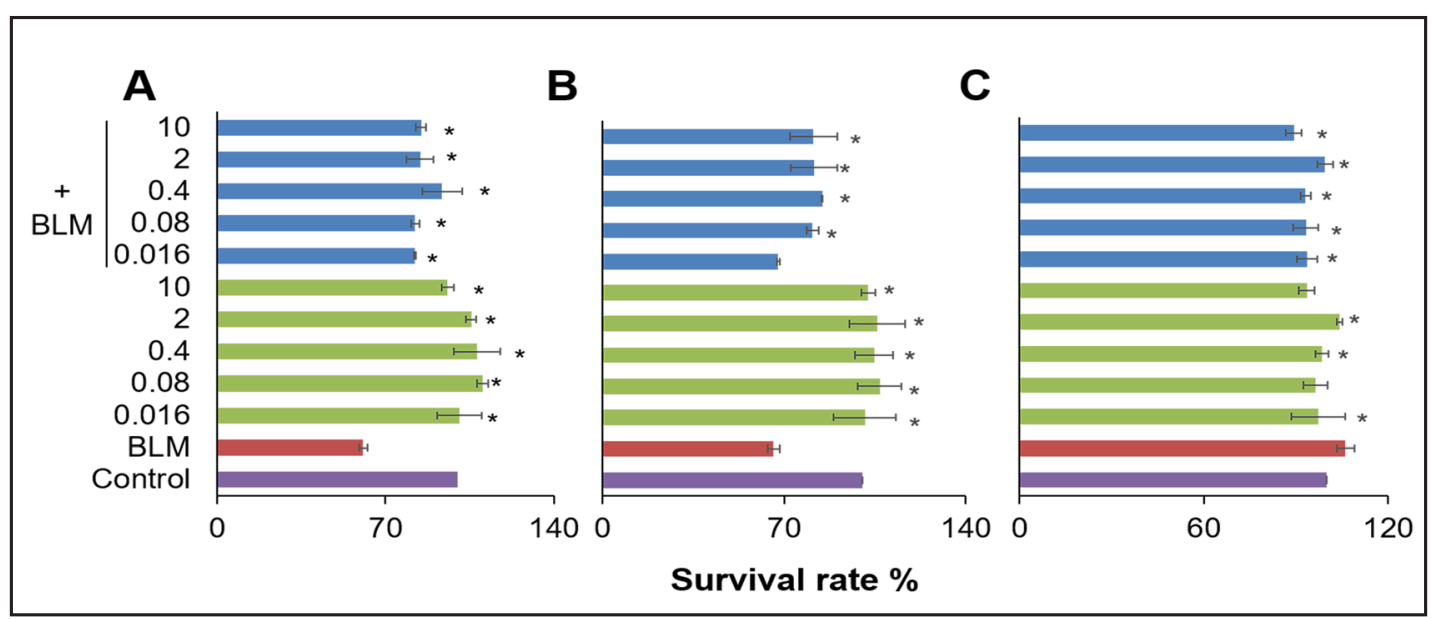

Fig. 3. Sulfation inhibition by sodium chlorate reduced cytotoxicity effects of bleomycin on cancer cell lines. Human colon cancer cell line HCT116 (A) and human lung cancer cell line A549 (B), and Chinese hamster ovary cell line CHO745 (C) were used to measure the percentage of viable cells after exposure to varying concentrations of sodium chlorate $(0.016-10 \mathrm{mM})$ with or without bleomycin $(15 \mu \mathrm{M})$. The experiment was repeated three times with similar results. The untreated cells (control) were assigned values of 100 and the results were presented as mean \pm S.D. $(n=3)$. Significance: ${ }^{*} \mathrm{P}<0.05$ vs bleomycin group.

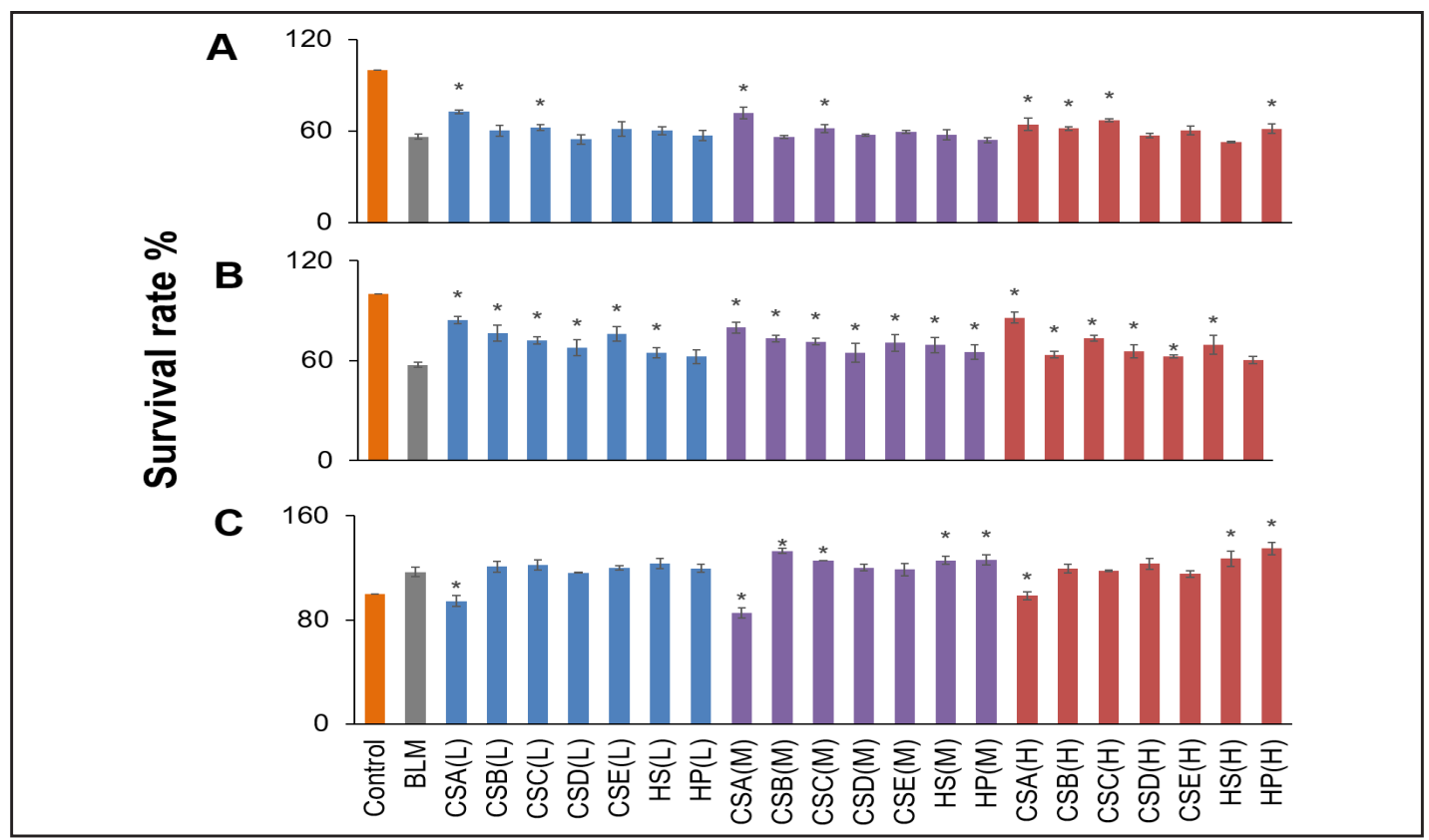

Fig. 4. Soluble GAG reduced cytotoxicity of bleomycin in both HCT116 and A549 cells. Human colon cancer cell line HCT116 (A) and human lung cancer cell line A549 (B), and Chinese hamster ovary cell line CHO745 (C) were used to measure the percentage of viable cells after $48 \mathrm{~h}$ exposure to varying concentrations of soluble GAG (L-0.15 $\mu \mathrm{M}, \mathrm{M}-1.5 \mu \mathrm{M}, \mathrm{H}-15 \mu \mathrm{M})$ in the presence of bleomycin $(15 \mu \mathrm{M})$ or bleomycin treatment alone $(15 \mu \mathrm{M})$. The GAGs used in the experiment include CS-A, CS-B, CS-C, CS-D, CS-E, HS, and heparin as described earlier [48]. Since different GAGs have different molecular weight distributions and bleomycin is a small molecule comparable to the size of a repeating disaccharide unit in the GAGs, the disaccharide concentration for each GAG was calculated based on the knowledge of its average mass of the repeating disaccharide unit. The experiment was repeated three times with similar results. The untreated cells (control) were assigned values of 100 and the results were presented as mean \pm S.D. $(n=3)$. Significance: $* \mathrm{P}<0.05$ vs. bleomycin group.

\section{KARGER}




\section{Cellular Physiology Cell Physiol Biochem 2017;43:1220-1234 \\ \begin{tabular}{l|l|l} 
DOI: 10.1159/000481763 & (0) 2017 The Author(s). Published by S. Karger AG, Basel \\
www.karger.com/cpb
\end{tabular} \\ Li et al.: Bleomycin Causes Undersulfation of Heparan Sulfate}

undersulfation of HS occurred in both HCT116 and A549 cells regardless the treatment time and the concentrations of bleomycin used (Fig. $1 \& 2$, and Tables $2 \& 3$ ). Thus, we concluded that BLEOMYCIN was a novel molecule that inhibited HS sulfation.

Since bleomycin induces lung tissue-specific damage that leads to fibrosis in certain cancer patients and in different animal models [49-51], our results would predict that the GAGs at lung epithelial cells might facilitate bleomycin uptake. Such experiment is currently conducted in our laboratory in a bleomycin-induced fibrosis mouse model.

Due to their template free biosynthesis, it is known that GAG structures are sensitive to drug treatment. We previously reported a 9-fold increase in GAG quantity after retinoic acid plus cAMP treatment of a F9 embryonal carcinoma cells by using a series of radio-active isotope involved assays [52]. To overcome the lacking of the access to radio-active isotope facilities, we used two radio-active material free assays to monitor the drug-induced changes in GAG structures in current studies. Moreover, the PMP- and D5PMP-labeling strategy allowed the quantity and disaccharide compositions in drug-treated and control cells to be compared simultaneously by LC/MS. (Fig. 2, Table 2). When coupled to reversed-phase LC, this assay permitted separation of nearly all known HS and CS disaccharides, including difficult to separate species bearing unsubstituted glucosamine residues, such as D2H0 and D0H6, as shown in Table 2.

This LC/MS assay failed to detect the tri-sulfated HS disaccharide, D2S6, a relatively low abundant disaccharide but did detect a rarer disaccharide D2H0 in HS from different animal tissues and cell lines that was documented in the past (Fig. 6 in [53]). Since the PMP-labeled D2S6 standard eluted and detected first by the LC-MS at lowest acetonitrile concentration, it required highest concentration to be detected compared to the rest of less sulfated and nonsulfated disaccharide standards. However, the D2S6 and the rest HS disaccharides in both heparin and porcine mucosa HS were detected and had correct disaccharide compositions by using the same assay (data not shown). Based on these facts, we concluded that the low abundant D2S6 in the A549 and HCT116 cells was below the detection limit of this assay. Nevertheless, this assay detected all possible CS and HS disaccharides except D2S6 when compared to all commercially available disaccharide standards (See details in Materials and methods).

We used $0.1 \%$ DMSO in all the control, at this concentration, DMSO was not toxic to both cell lines tested. However, LC/MS analysis (Table 2) showed that the control cells did not produce identical disaccharide compositions when exposed to $0.1 \%$ DMSO for short or longer periods of exposure (Table 3), which suggested that $0.1 \%$ DMSO might affect GAG biosynthesis in both HCT116 and A549 cells.

Resistance to bleomycin and bleomycin-induced lung fibrosis are two major clinical concerns [30]. Fibrosis, a hallmark of clinical diseases that affects the normal functions of lung, liver, heart, or kidney, is defined as an abnormal accumulation of extracellular matrix components. HS and CS GAGs are key components in extracellular matrix. Lung fibrosis is induced in certain cancer patients treated with BLEOMYCIN with molecular mechanisms largely unknown. Bleomycin is the mostly used chemical in inducing lung fibrosis in animal models $[8,51]$. Both FGF- 2 and TGF- $\beta$ signaling pathways play major roles in the fibrosis process and GAGs are co-regulators of both FGF- 2 and TGF- $\beta$ pathways $[54,55]$. It is reported that a CS proteoglycan biglycan forms a complex with either transforming growth factor- $\beta_{1}$ or the transforming growth factor- $\beta_{1}$ type I receptor and to intensify the phosphorylation of Smad2/3, resulting in a lower expression of the transmembrane heparan sulfate proteoglycan, syndecan-4 [56]. Our results show that CS sulfation was not affected by bleomycin treatment as much as HS sulfation, which suggests that the balance between HS and CS was disrupted by the bleomycin in favor of TGF- $\beta$ signaling during lung fibrosis. However, all most all cells make both HS and CS. Bleomycin only induces lung but not liver, heart, or kidney fibrosis in certain patients and in animals, which suggest the lung environment, especially the bleomycin-induced changes in HS and CS compositions and structures, might contribute to the reported observations. We are currently comparing the bleomycin-induced changes in HS and CS composition and structures isolated from lung, liver, heart, or kidney tissues using 
PMP-tagging and LC-MS detecting method presented in current study in a mouse model of bleomycin-induced lung fibrosis.

All mammalian cells are covered by a surface layer of glycans that is referred to as the 'glycocalyx'. The major components of the glycocalyx are GAGs and the thickness of the glycocalyx is 50 to 100 times more than that of the cell membrane phospholipid bilayer [57]. However, the glycocalyx is a highly dynamic and fragile structure ex vivo, traditional tissue processing for staining and perfusion-fixation usually results in a partial or complete loss of the glycocalyx [58]. Moreover, the variable GAG structures are difficult to define compared to that of DNAs, RNAs, and proteins, the roles of glycocalyx and GAGs played in biology and medicine are largely ignored during the past. Thus, the method of stable isotope-labeling coupled with LC/MS analysis of GAG disaccharide compositions used in current study would be a valid assay to explore the bleomycin-affected GAG biology in the post-genomic era.

\section{Abbreviations}

GAGs (glycosaminoglycans ); HS (heparan sulfate); CS (chondroitin sulfate); GlcA (glucuronic acid); IdoA (iduronic acid); GlcNAc ( $N$-acetylglucosamine); GlcNS ( $N$-sulfated glucosamine); GlcN (glucosamine); GalN (galactosamine); PMP (1-phenyl-3-methyl-5pyrazolone); D5PMP (2, 3,4, 5,6-deuterated 1-phenyl-3-methyl-5-pyrazolone); MS (mass spectrometry); LC (liquid chromatography).

\section{Acknowledgements}

The correspondence author would like to thank Professor Jeffrey D. Esko for introducing her to the different aspects of glycosaminoglycan research and his excellent mentorship since 1990 and thank Professor Robert Rosenberg for convincing her to use LC/MS to study glycosaminoglycan structures since 1995. This research was supported by the Natural Science Foundation of China (Grant 81672585), Key Technology Fund of Shandong Province (Grant 2016ZDJS07A07), and the "Double First Class" Fund of Shandong Province.

\section{Disclosure Statement}

The authors declare that they have no conflicts of interest with the contents of this article.

\section{References}

$>1$ Sneader WE: Drug Discovery (The History). Wiley Online Library, 2005.

2 Organization WH: WHO model list of essential medicines, 18th list, 2013. http://www.who.int/medicines/ publications/essentialmedicines/18th_EML_Final_web_8Jul13.pdf.

3 Belehradek JJ, Orlowski S, Ramirez LH, Pron G, Poddevin B, Mir LM: Electropermeabilization of cells in tissues assessed by the qualitative and quantitative electroloading of bleomycin. Biochim Biophys Acta 1994;1190:155-163.

4 Li WS, Wei SC, Liang SZ: The use of two-route Cisplatin chemotherapy in the treatment of oral squamous cell carcinoma. Shanghai Kou Qiang Yi Xue 2000;9:76-78.

5 Hoffmann GR, Quaranta JL, Shorter RA, Littlefield LG: Modulation of bleomycin-induced mitotic recombination in yeast by the aminothiols cysteamine and WR-1065. Mol Gen Genet 1995;249:366-374.

6 Williamson JD, Sadofsky LR, Hart SP: The pathogenesis of bleomycin-induced lung injury in animals and its applicability to human idiopathic pulmonary fibrosis. Exp Lung Res 2015;41:57-73. 


\section{Cellular Physiology Cell Physiol Biochem 2017;43:1220-1234 \begin{tabular}{l|l|l} 
and BOI: 10.1159/000481763 & $\begin{array}{l}\text { C } 2017 \text { The Author(s). Published by S. Karger AG, Basel } \\
\text { www.karger.com/cpb }\end{array}$
\end{tabular} \\ Li et al.: Bleomycin Causes Undersulfation of Heparan Sulfate}

7 Yu X, Lin Q Qin X, Ruan Z, Zhou J, Lin Z, Su Y, Zheng J, Liu Z: ACE2 antagonizes VEGFa to reduce vascular permeability during acute lung injury. Cell Physiol Biochem 2016;38:1055-1062.

8 Li L, Zhang H, Min D, Zhang R, Wu J, Qu H, Tang Y: Sox9 activation is essential for the recovery of lung function after acute lung injury. Cell Physiol Biochem 2015;37:1113-1122.

-9 Zhang L: Glycosaminoglycan (GAG) biosynthesis and GAG-binding proteins. Prog Mol Biol Transl Sci 2010;93:1-17.

10 Shi X, Zaia J: Organ-specific heparan sulfate structural phenotypes. J Biol Chem 2009;284:11806-11814.

11 Sawant KV, Poluri KM, Dutta AK, Sepuru KM, Troshkina A, Garofalo RP, Rajarathnam K: Chemokine CXCL1 mediated neutrophil recruitment: Role of glycosaminoglycan interactions. Sci Rep 2016;6:33123.

12 Yanagishita M, Hascall VC: Cell surface heparan sulfate proteoglycans. J Biol Chem 1992;267:9451-9454.

13 Esko JD, Selleck SB: Order out of chaos: Assembly of ligand binding sites in heparan sulfate. Annu Rev Biochem 2002;71:435-471.

14 Izumikawa T, Sato B, Kitagawa H: Chondroitin sulfate is indispensable for pluripotency and differentiation of mouse embryonic stem cells. Sci Rep 2014;4:3701.

15 Li Q Park PW, Wilson CL, Parks WC: Matrilysin shedding of syndecan-1 regulates chemokine mobilization and transepithelial efflux of neutrophils in acute lung injury. Cell 2002;111:635-646.

16 Vlodavsky I, Friedmann Y: Molecular properties and involvement of heparanase in cancer metastasis and angiogenesis. J Clin Invest 2001;108:341-347.

17 D’Antoni ML, Torregiani C, Ferraro P, Michoud MC, Mazer B, Martin JG, Ludwig MS: Effects of decorin and biglycan on human airway smooth muscle cell proliferation and apoptosis. Am J Physiol Lung Cell Mol Physiol 2008;294:L764-L771.

18 Jiang D, Liang J, Campanella GS, Guo R, Yu S, Xie T, Liu N, Jung Y, Homer R, Meltzer EB, Li Y, Tager AM, Goetinck PF, Luster AD, Noble PW: Inhibition of pulmonary fibrosis in mice by CXCL10 requires glycosaminoglycan binding and syndecan-4. J Clin Invest 2010;120:2049-2057.

-19 Lord MS, Chuang CY, Melrose J, Davies MJ, Iozzo RV, Whitelock JM: The role of vascular-derived perlecan in modulating cell adhesion, proliferation and growth factor signaling. Matrix Biol 2014;35:112-122.

20 Burhan I, Furini G, Lortat-Jacob H, Atobatele AG, Scarpellini A, Schroeder N, Atkinson J, Maamra M, Nutter FH, Watson P, Vinciguerra M, Johnson TS, Verderio EA: Interplay between transglutaminases and heparan sulphate in progressive renal scarring. Sci Rep 2016;6:31343.

21 Holley RJ, Meade KA, Merry CL: Using embryonic stem cells to understand how glycosaminoglycans regulate differentiation. Biochem Soc Trans 2014;42:689-695.

22 Amadi B, Fagbemi AO, Kelly P, Mwiya M, Torrente F, Salvestrini C, Day R, Golden MH, Eklund EA, Freeze HH, Murch SH: Reduced production of sulfated glycosaminoglycans occurs in Zambian children with kwashiorkor but not marasmus. Am J Clin Nutr 2009;89:592-600.

-23 Tsara ME, Papageorgacopoulou N, Karavias DD, Theocharis DA: Distribution and changes of glycosaminoglycans in neoplasias of rectum. Anticancer Res 1995;15:2107-2112.

24 Levy P, Munier A, Baron-Delage S, Di Gioia Y, Gespach C, Capeau J, Cherqui G: Syndecan-1 alterations during the tumorigenic progression of human colonic Caco-2 cells induced by human Ha-ras or polyoma middle $\mathrm{T}$ oncogenes. Br J Cancer 1996;74:423-431..

-25 David G, Van Den Berghe H: Transformed mouse mammary epithelial cells synthesize undersulfated basement membrane proteoglycan. J Biol Chem 1983;258:7338-7344.

-26 Kaner RJ, Iozzo RV, Ziaie Z, Kefalides NA: Inhibition of proteoglycan synthesis in human endothelial cells after infection with herpes simplex virus type 1 in vitro. Am J Respir Cell Mol Biol 1990;2:423-431.

27 Baeuerle PA, Huttner WB: Chlorate--a potent inhibitor of protein sulfation in intact cells. Biochem Biophys Res Commun 1986;141:870-877.

28 Garud DR, Tran VM, Victor XV, Koketsu M, Kuberan B: Inhibition of heparan sulfate and chondroitin sulfate proteoglycan biosynthesis. J Biol Chem 2008;283:28881-28887.

29 Tounekti O, Pron G, Belehradek JJ, Mir LM: Bleomycin, an apoptosis-mimetic drug that induces two types of cell death depending on the number of molecules internalized. Cancer Res 1993;53:5462-5469.

-30 Wang Q, Cui K, Espin-Garcia O, Cheng D, Qiu X, Chen Z, Moore M, Bristow RG, Xu W, Der S, Liu G: Resistance to bleomycin in cancer cell lines is characterized by prolonged doubling time, reduced DNA damage and evasion of G2/M arrest and apoptosis. PLoS One 2013;8:e82363.

-31 Christianson HC, Belting M: Heparan sulfate proteoglycan as a cell-surface endocytosis receptor. Matrix Biol 2014;35:51-55. 


\section{Cellular Physiology Cell Physiol Biochem 2017;43:1220-1234 \begin{tabular}{l|l|l} 
and BOI: 10.1159/000481763 & $\begin{array}{l}\text { C) } 2017 \text { The Author(s). Published by S. Karger AG, Basel } \\
\text { www.karger.com/cpb }\end{array}$
\end{tabular}}

Li et al.: Bleomycin Causes Undersulfation of Heparan Sulfate

32 Naik RJ, Sharma R, Nisakar D, Purohit G, Ganguli M: Exogenous chondroitin sulfate glycosaminoglycan associate with arginine-rich peptide-DNA complexes to alter their intracellular processing and gene delivery efficiency. Biochim Biophys Acta 2015;1848:1053-1064.

33 Piva MB, Suarez ER, Melo CM, Cavalheiro RP, Nader HB, Pinhal MA: Glycosaminoglycans affect heparanase location in CHO cell lines. Glycobiology 2015;25:976-983.

-34 Christianson HC, Belting M: Heparan sulfate proteoglycan as a cell-surface endocytosis receptor. Matrix Biol 2014;35:51-55.

35 He Y, Lan Y, Liu Y, Yu H, Han Z, Li X, Zhang L: Pingyangmycin and bleomycin share the same cytotoxicity pathway. Molecules 2016;21:862.

-36 Tong S, Zhang M, Wang S, Yin R, Yu R, Wan S, Jiang T, Zhang L: Isothiouronium modification empowers pyrimidine-substituted curcumin analogs potent cytotoxicity and Golgi localization. Eur J Med Chem 2016;123:849-857.

-37 Venkatesan N, Roughley PJ, Ludwig MS: Proteoglycan expression in bleomycin lung fibroblasts: Role of transforming growth factor-beta(1) and interferon-gamma. Am J Physiol Lung Cell Mol Physiol 2002;283:L806-L814.

38 Venkatesan N, Ebihara T, Roughley PJ, Ludwig MS: Alterations in large and small proteoglycans in bleomycin-induced pulmonary fibrosis in rats. Am J Respir Crit Care Med 2000;161:2066-2073.

39 Venkatesan N, Ouzzine M, Kolb M, Netter P, Ludwig MS: Increased deposition of chondroitin/dermatan sulfate glycosaminoglycan and upregulation of beta1, 3-glucuronosyltransferase I in pulmonary fibrosis. Am J Physiol Lung Cell Mol Physiol 2011;300:L191-L203.

40 Yin R, Zhang M, Hao C, Wang W, Qiu P, Wan S, Zhang L, Jiang T: Different cytotoxicities and cellular localizations of novel quindoline derivatives with or without boronic acid modifications in cancer cells. Chem Commun 2013;49:8516-8518.

-41 Dundar M, Muller T, Zhang Q, Pan J, Steinmann B, Vodopiutz J, Gruber R, Sonoda T, Krabichler B, Utermann G, Baenziger JU, Zhang L, Janecke AR: Loss of dermatan-4-sulfotransferase 1 function results in adducted thumb-clubfoot syndrome. Am J Hum Genet 2009;85:873-882.

-42 Lu H, McDowell LM, Studelska DR, Zhang L: Glycosaminoglycans in human and bovine serum: Detection of Twenty-Four heparan sulfate and chondroitin sulfate motifs including a novel sialic acid-modified chondroitin sulfate linkage hexasaccharide. Glycobiol Insights 2010;2010:13-28.

43 Han Z, Zeng Y, Zhang M, Zhang Y, Zhang L: Monosaccharide compositions of sulfated chitosans obtained by analysis of nitrous acid degraded and pyrazolone-labeled products. Carbohydr Polym 2016;136:376-383.

44 Ramotar D, Wang H: Protective mechanisms against the antitumor agent bleomycin: Lessons from Saccharomyces cerevisiae. Curr Genet 2003;43:213-224.

45 Poddevin B, Orlowski S, Belehradek JJ, Mir LM: Very high cytotoxicity of bleomycin introduced into the cytosol of cells in culture. Biochem Pharmacol 1991;42:S67-S75.

-46 Orlowski S, Belehradek JJ, Paoletti C, Mir LM: Transient electropermeabilization of cells in culture. Increase of the cytotoxicity of anticancer drugs. Biochem Pharmacol 1988;37:4727-4733.

-47 Aouida M, Tounekti O, Belhadj O, Mir LM: Comparative roles of the cell wall and cell membrane in limiting uptake of xenobiotic molecules by Saccharomyces cerevisiae. Antimicrob Agents Chemother 2003;47:20122014.

\$8 Avirutnan P, Zhang L, Punyadee N, Manuyakorn A, Puttikhunt C, Kasinrerk W, Malasit P, Atkinson JP, Diamond MS: Secreted NS1 of dengue virus attaches to the surface of cells via interactions with heparan sulfate and chondroitin sulfate E. PLoS Pathog 2007;3:e183.

49 Bao H, Gao F, Xie G, Liu Z: Angiotensin-Converting enzyme 2 inhibits apoptosis of pulmonary endothelial cells during acute lung injury through suppressing MiR-4262. Cell Physiol Biochem 2015;37:759-767.

50 Liu S, Tang J, Huang L, Xu Q, Ling X, Liu J: Cordyceps militaris alleviates severity of murine acute lung injury through miRNAs-Mediated CXCR2 inhibition. Cell Physiol Biochem 2015;36:2003-2011.

51 Wang L, Wang Y, Yang T, Guo Y, Sun T: Angiotensin-Converting Enzyme 2 Attenuates Bleomycin-Induced Lung Fibrosis in Mice. Cell Physiol Biochem 2015;36:697-711.

52 Zhang X, Ibrahimi OA, Olsen SK, Umemori H, Mohammadi M, Ornitz DM: Receptor specificity of the fibroblast growth factor family. The complete mammalian FGF family. J Biol Chem 2006;281:15694-15700.

-53 Guimond SE, Puvirajesinghe TM, Skidmore MA, Kalus I, Dierks T, Yates EA, Turnbull JE: Rapid purification and high sensitivity analysis of heparan sulfate from cells and tissues: Toward glycomics profiling. J Biol Chem 2009;284:25714-25722. 


\section{Cellular Physiology Cell Physiol Biochem 2017;43:1220-1234

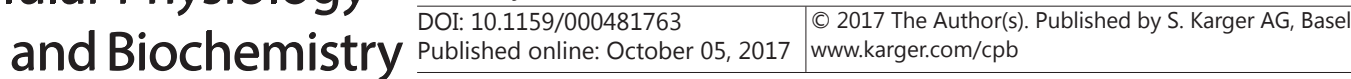 \\ Li et al.: Bleomycin Causes Undersulfation of Heparan Sulfate}

54 McDowell LM, Frazier BA, Studelska DR, Giljum K, Chen J, Liu J, Yu K, Ornitz DM, Zhang L: Inhibition or activation of Apert syndrome FGFR2 (S252W) signaling by specific glycosaminoglycans. J Biol Chem 2006;281:6924-6930.

55 Rider CC, Mulloy B: Heparin, heparan sulphate and the TGF-beta cytokine superfamily. Molecules 2017;22

\$56 Hara T, Yoshida E, Shinkai Y, Yamamoto C, Fujiwara Y, Kumagai Y, Kaji T: Biglycan intensifies ALK5-Smad2/3 signaling by TGF-beta1 and downregulates syndecan-4 in cultured vascular endothelial cells. J Cell Biochem 2017;118:1087-1096.

57 Tarbell JM, Cancel LM: The glycocalyx and its significance in human medicine. J Intern Med 2016;280:97113.

58 Dane MJ, van den Berg BM, Lee DH, Boels MG, Tiemeier GL, Avramut MC, van Zonneveld AJ, van der Vlag J, Vink H, Rabelink TJ: A microscopic view on the renal endothelial glycocalyx. Am J Physiol Renal Physiol 2015;308:F956-F966.

59 Lawrence R, Lu H, Rosenberg RD, Esko JD, Zhang L: Disaccharide structure code for the easy representation of constituent oligosaccharides from glycosaminoglycans. Nat Methods 2008;5:291-292. 